\title{
Forum
}

\section{Redistribution of Runoff Among Vegetation Patch Types: On Ecohydrological Optimality of Herbaceous Capture of Run-On}

\author{
Anna M. Urgeghe, ${ }^{1}$ David D. Breshears, ${ }^{2}$ Scott N. Martens, ${ }^{3}$ and Peter C. Beeson ${ }^{4}$ \\ Authors are ${ }^{1} \mathrm{PhD}$ Candidate, Departamento de Ecología, Universidad de Alicante, 03690 Alicante, Spain; ${ }^{2}$ Professor, School of Natural Resources and \\ the Environment and Department of Ecology and Evolutionary Biology, University of Arizona, Tucson, AZ 85721, USA; ${ }^{3}$ Senior Scientist, Sierra Science, \\ PO Box 461, Three Rivers, CA 93271, USA; and ${ }^{4}$ Researcher, Earth and Environmental Science, Los Alamos National Laboratory, \\ Los Alamos, NM 87545, USA.
}

\begin{abstract}
A central tenant of ecohydrology in drylands is that runoff redistribution from bare to vegetated patches concentrates the key limiting resource of water, which can then enhance vegetation growth and biomass. Conversely, a reduction in vegetation patches, particularly those associated with herbaceous plants, can lead to a threshold-like response in which bare patches become highly interconnected, triggering a large increase in hillslope runoff and associated erosion. However, generally lacking is an assessment of how maximization of run-on to herbaceous patches relates to minimization of hillslope-scale runoff. To illustrate how runoff redistribution potentially changes in response to conversion of herbaceous patches to bare ones, we used a spatially distributed model, SPLASH (Simulator for Processes at the Landscape Surface-Subsurface Hydrology), with an example of a semiarid piñon-juniper woodland hillslope with seven combinations of bare and herbaceous patch cover, culminating in complete loss of herbaceous patches, for a 1-yr design storm. As expected, the amount of hillslope runoff increased curvilinearly with reductions in herbaceous cover as runoff per cell increased from bare patches and run-on per cell increased for herbaceous patches. Notably, the total amount of run-on to all herbaceous patches was greatest when the amount of bare cover was intermediate, highlighting a trade-off between the source area for generating runoff and the sink area for capturing run-on. The specific nature of patch-hillslope runoff redistribution responses certainly depends on several site-specific conditions, but the general nature of the response exhibited in our example simulation may be indicative of a general type of response applicable to many rangelands. We suggest that a more robust suite of such relationships could be valuable for managing rangelands by enabling explicit accounting for optimality and trade-offs in biomass per herbaceous patch, total herbaceous cover, and prevention of hillslope-scale connectivity of bare patches that triggers a large increase in runoff and associated erosion.
\end{abstract}

\section{Resumen}

Un postulado central de la ecohidrología de tierras áridas es que la redistribución de la escorrentía desde parches de suelo desnudo hacia parches de vegetación concentra el recurso clave limitante, el agua, que a su vez puede mejorar el crecimiento y la biomasa de la vegetación. Por otro lado, una reducción en los parches de vegetación, particularmente aquellos asociados con plantas herbáceas, puede conducir a una dinámica de umbral en la que la interconexión de los parches de suelo desnudo incrementa de modo tal que se desencadena un incremento considerable en la escorrentía y la erosión asociada. Sin embargo, generalmente faltan evaluaciones de cómo la maximización de recepción de agua de escorrentía en parches de vegetación herbácea está relacionada con la minimización de la escorrentía a escala de ladera. A fin de ilustrar el modo en que la redistribución asociada a la escorrentía puede cambiar como consecuencia de la conversión de parches herbáceos a parches de suelo desnudo utilizamos el modelo espacialmente distribuido SPLASH (simulador para procesos de hidrología superficial-subsuperficial a escala de paisaje), con un ejemplo de una ladera con monte semiárido de Pinus sp. y Juniperus sp. con siete combinaciones de parches herbáceos y de suelo desnudo, culminando en una pérdida total de parches herbáceos, en un diseño de tormentas de 1 año. Como era de prever, la cantidad de escorrentía de ladera aumentó de modo curvilíneo con la reducción de cobertura herbácea; la escorrentía desde los parches de suelo desnudo de cada celda aumentó y la recepción del agua de escorrentía de los parches herbáceos también aumentóen cada celda del modelo. Llama la atención que la cantidad total de agua de escorrentía recibida por los parches herbáceos alcanzó valores máximos con valores intermedios de cobertura de suelo desnudo, hecho que resalta el compromiso existente entre el área de fuentes de agua escorrentía y las áreas de sumidero para la captura de dicha escorrentía. La naturaleza especifica de la relación entre parches y redistribución de la escorrentía sin dudas

Research was funded by Los Alamos Environmental Restoration, National Science Foundation Critical Zone Observatory (NSF EAR-0724958), Department of Energy National Institute for Climate Change Research (Western Region; DE-FCO2-06ER64159), and Arizona Agricultural Experiment Station. A.M.U. was supported by a Formación de Profesorado Universitario fellowship from the Spanish Ministry of Education (AP 2007-03062) to collaborate at the University of Arizona.

At the time of the research, Urgeghe was a visiting student at the School of Natural Resources and the Environment, University of Arizona, Tucson, AZ 85721, USA.

Correspondence: David D. Breshears, School of Natural Resources and the Environment, 1311 East Fourth Street, BioSciences East 325, University of Arizona, Tucson, AZ 85737, USA. Email: daveb@email.arizona.edu

Current address: Peter C. Beeson, US Department of Agriculture Agricultural Research Service Hydrology and Remote Sensing Laboratory, Beltsville, MD 20705, USA.

Manuscript received 10 December 2009; manuscript accepted 16 March 2010. 
depende de varias condiciones sitio-especificas, pero la naturaleza de la respuesta exhibida en nuestro ejemplo de simulación podría ser indicativa de una respuesta de tipo general aplicable a muchos pastizales naturales. Sugerimos que un conjunto más robusto de dichas relaciones podría ser valioso para el manejo de pastizales naturales permitiendo tomar en cuenta la optimización y el compromiso entre la biomasa por parche herbáceo, la cobertura vegetal total, y la prevención de la conectividad de parches de suelo desnudo a escala de ladera que desencadena un aumento en la escorrentía y erosión asociada.

Key Words: ecohydrology, runoff redistribution, run-on, threshold response, vegetation patch types, woodland

\section{INTRODUCTION}

A central tenant of ecohydrology is that the water budget and vegetation patterns and dynamics are tightly interrelated in rangelands and other water-limited ecosystems (Noy-Meir 1973; Rodríguez-Iturbe 2000; Eagleson 2002; Ludwig et al. 2005). Understanding these ecohydrological interrelationships is becoming increasingly important for effective rangeland management by scientific, management, and policy communities (Newman et al. 2006; Wilcox and Thurow 2006), particularly as rangeland degradation continues to progress in a significant portion of the world's semiarid regions (Middleton and Thomas 1997). Degradation of rangeland is often preceded by a reduction in vegetation cover (Dregne 2002). One of the first manifestations of loss of vegetation cover is altered redistribution of water on the landscape (Cornet et al. 1992; Bhark and Small 2003). For this reason, both vegetation and runoff, as well as their interactions, have been used to evaluate the health and the functionality of semiarid rangelands (Ludwig and Tongway 1995; Ludwig et al. 1997). In addition, recent studies have highlighted the use of cover and vegetation pattern as indicators of rangeland health in monitoring and management approaches and protocols (Pyke et al. 2002; Herrick et al. 2005). Reductions in herbaceous cover following disturbances such as grazing or fire are considered short-term indicators of rangeland health and are useful for rangeland management, particularly as key indicators of threshold transitions (Herrick et al. 2006).

Ecohydrological relationships between vegetation cover and runoff-erosion have become of particular concern because of the threshold-like response (sensu Briske et al. 2006) that can occur as herbaceous cover is progressively removed and the resulting bare batches become highly interconnected at the hillslope scale (Imeson and Lavee 1998; Wilcox et al. 2003a). In most semiarid shrublands and woodlands, the vegetation is a mosaic of patch types composed of the canopies of woody plants and the intercanopies that separate them, the latter of which include patches of herbaceous or bare soil cover (Wilcox et al. 2003a; Fig. 1A).

In these environments, runoff processes, as well as erosion dynamics, are scale-dependent and have a feedback in that vegetation cover is a primary determinant of runoff, while redistribution of runoff can affect vegetation patterns (Wilcox et al. 2003a; Ludwig et al. 2005). Runoff is greatest from intercanopy bare patches (Reid et al. 1999) and in woodlands is redistributed either to the canopy patches of woody plants and/ or to intercanopy herbaceous patches (Ludwig and Tongway 1995; Anderson and Hodgkinson 1997; Weltz et al. 1998; Wilcox et al. 2003a; Pierson et al. 2009). The intercanopy herbaceous patches act as sinks for capturing runoff, nutrients, and sediments that flow from intercanopy bare patches, which serve as sources (Noy-Meir 1973; Tongway and Ludwig 1997;
Schlesinger et al. 2000; Wainwright et al. 2000; Wilcox et al. 2003a). These dynamics have implications for other ecosystem processes, such as primary productivity: the inputs of water and nutrients to herbaceous patches can produce an enhanced pulse of plant growth that, in turn, should maintain or even increase the capacity of these patches to retain runoff (Ludwig et al. 2005).

Several field and modeling studies in rangelands have documented how different patch types influence overland water flow (Abrahams et al. 1995; Bergkamp 1998; Reid et al. 1999; Schlesinger et al. 1999, 2000; Wilcox et al. 2003a; Bautista et al. 2007; Lesschen et al. 2009). Additionally, lower amounts of herbaceous cover are associated with higher runoff amounts (Elwell and Stocking 1976; Thornes 1990; Tongway and Ludwig 1997; Davenport et al. 1998; Boer and Puigdefábregas 2005; Bartley et al. 2006). A simple conceptual model based on percolation theory can illustrate how a threshold-like increase in runoff occurs in response to reduction of herbaceous cover (Davenport et al. 1998). Consequently, rangeland models are evolving to account for threshold-like behavior (Ludwig et al. 1997).

Reconcentration of water as runoff from bare patches to runon for herbaceous patches can be important because soil moisture delivered as a deeper pulse is less prone to high evaporative losses and may provide more "plant-available water" (McDonald et al. 2009). Such reconcentration of water depends on the amount of bare patches present. Minimizing bare cover minimizes the potential for reconcentration of runoff as run-on to other vegetation patches, even though minimizing bare cover simultaneously minimizes hillslope runoff. Therefore, there is likely a trade-off between source area for generating runoff and sink area for capturing run-on. If there is too little redistribution of runoff from bare patches, herbaceous patches will have to make do with only existing precipitation. If there is too little herbaceous cover, water is lost from the hillslope. But for some intermediate amount of herbaceous cover, there should be a value for which the total amount of water leaving bare patches is optimal for the total amount of run-on captured by herbaceous patches. More explicit consideration of this relationship has the potential to improve rangeland management.

In this article, we explore how maximization of run-on to herbaceous patches relates to minimization of hillslope-scale runoff. We provide an example using a spatially explicit simulation model to quantitatively decrease the proportion of patches of herbaceous cover as an analogue for rangeland degradation. We simulated overland flow and runoff redistribution at patch and hillslope scales for seven different levels of herbaceous cover for a semiarid piñon-juniper woodland. The specific nature of patch-hillslope runoff redistribution responses will depend on several site-specific conditions, but the general nature of the response illustrated in our example 
A

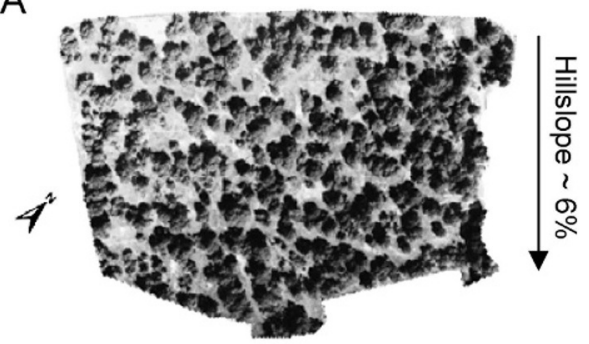

Cover:

.Canopy $55 \%$

-Grass 35\%

.Bare 10\%

B

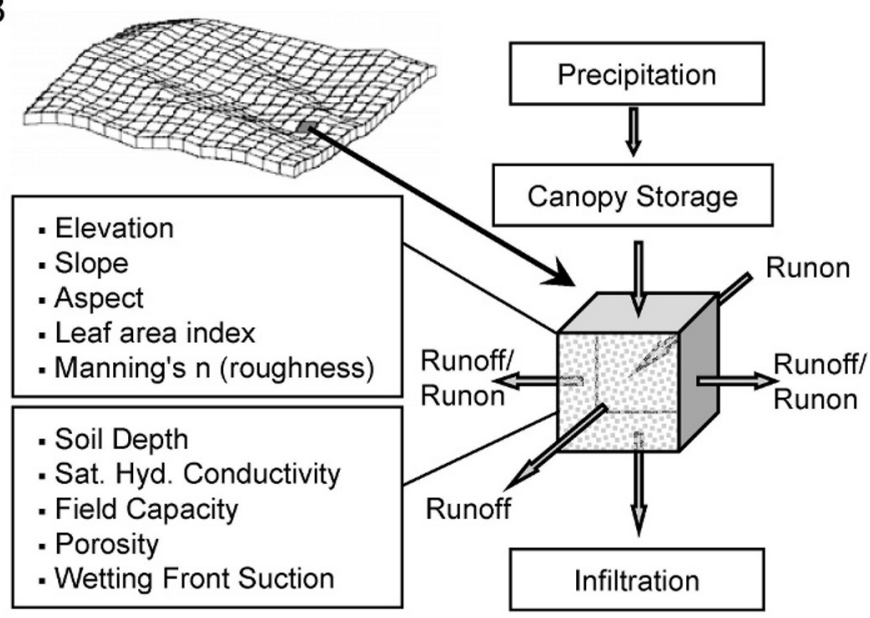

C

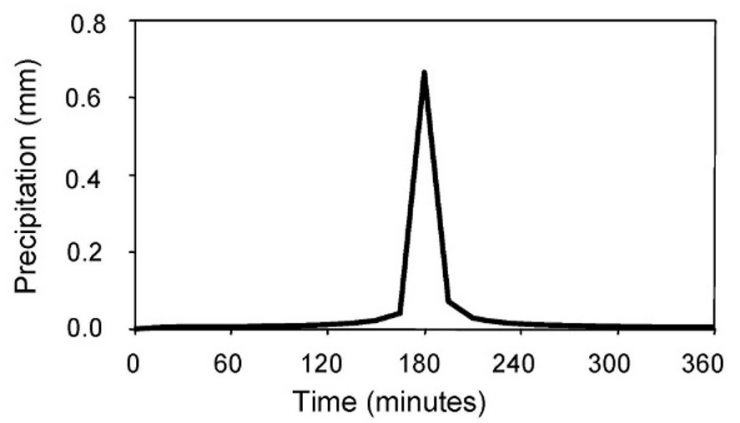

D

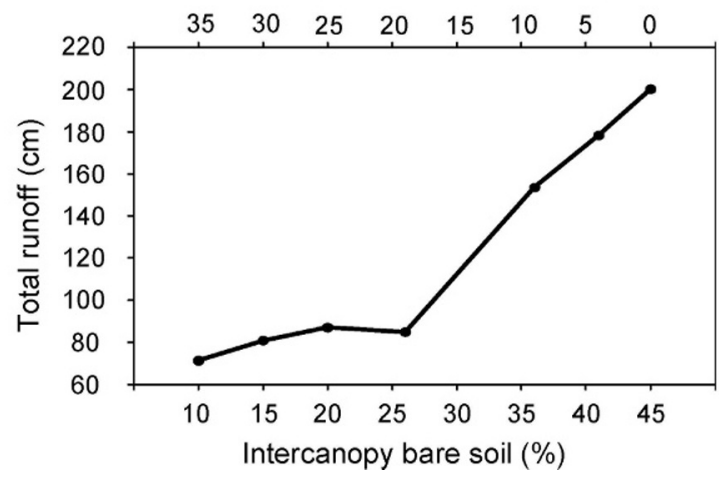

Figure 1. A, Example simulated hillslope with tree canopy patches, intercanopy herbaceous patches, and intercanopy bare patches (some shadows associated with low sun angle are also present). B, Simplified presentation of the SPLASH (Simulator for Processes at the Landscape Surface-Subsurface Hydrology) model that spatially redistributes water among vegetation patch types. C, Hyetograph of a 1-yr design storm of simulations may be broadly applicable to rangelands. We suggest that a more robust suite of such relationships could be valuable for managing rangelands by enabling explicit accounting for optimality and trade-offs in biomass per herbaceous patch, total herbaceous cover, and prevention of hillslope-scale connectivity of bare patches that triggers a large increase in runoff and loss of soil sediments and associated nutrients.

\section{A MODELING EXAMPLE OF HERBACEOUS CAPTURE OF RUN-ON}

\section{Modeling Approach}

We used a spatially explicit model for evaluating the redistribution of runoff as a function of the amount of herbaceous intercanopy cover (Fig. 1). The model, Simulator for Processes at the Landscape Surface-Subsurface Hydrology (SPLASH; Beeson et al. 2001; Martens and Breshears 2005), simulates lateral flows of surface water and groundwater, infiltration, evapotranspiration from a vegetation canopy, an energy balance approach for snowpack calculations, and a climate simulator. Four attributes of SPLASH are important for our study: physical representation of surface water routing, topographic shading, surface/subsurface hydrological coupling, and physically and biologically based representation of evaporation and transpiration. The model can be used for both short- and long-term applications by varying the time step, and it is able to use elevation lapse functions for temperature and precipitation.

The input data for grid cells in the SPLASH model include elevations from a digital elevation model (DEM), six soil physical parameters (surface roughness and soil depth, hydrologic conductivity, field capacity, porosity and wetting front suction), and leaf area index (LAI). SPLASH uses an explicit, finite-difference calculation scheme, which allows algorithm simplicity. In SPLASH, simulations of overland flow are based on Manning's equation (Dingman 1993). Water flow is calculated into and out of grid cells through the four sides of each cell, two in the $x$ direction and two in the $y$ direction (Fig. 1B). Velocities as well as discharges are calculated separately for each direction. For example, in the $x$ direction, the velocity, $u\left(\mathrm{~m} \cdot \mathrm{s}^{-1}\right)$, is calculated as

$$
u=(1 / n) h_{s}{ }^{2 / 3} S_{x}{ }^{1 / 2}
$$

where $n$ is Manning's roughness coefficient, $h_{s}$ is the hydraulic radius $(\mathrm{m})$ and reduces to flow depth (surface head) for overland flow, and $S_{x}$ is the slope of surface head in the $x$ direction $\left(\mathrm{m} \cdot \mathrm{m}^{-1}\right)$. Discharge, $Q\left(\mathrm{~m}^{3} \cdot \mathrm{s}^{-1}\right)$, is calculated as the product of velocity and cross-sectional area $\left(h_{s} \cdot\right.$ cell size).

Overland flow can be considered gradually varying sheetflow where the energy source for flow (gravity) is consumed by friction. Water moves in the direction of steepest descent (aspect) based on the DEM, and water ponded on the surface (e.g., saturation excess, infiltration excess) is subject to flow.

$\leftarrow$

$10 \mathrm{~mm}$ for the example study area. D, Runoff at the hillslope scale as a function of the percentage of the intercanopy herbaceous cover (top $X$ axis) and the intercanopy bare soil (bottom $\mathrm{X}$ axis). 
Usually, the slope of the water surface can be calculated as the gradient between two cells (diffusive wave approximation). (Optionally, it may be assumed parallel to the bed [DEM] surface [kinematic wave approximation].) This allows SPLASH to simulate backwater effects and ponding of water in topographic depressions that may then overflow. Channel flow is not explicitly included in SPLASH but takes place only inasmuch as "channels" are defined by the DEM.

Time step size $\Delta t$ is dynamically determined by SPLASH and depends on a user-defined Courant number $c \quad(0<c \leq 1$; Courant et al. 1928), the cell size $x$, and the maximum flow velocity on the grid at the previous time step $v_{\max }$ such that maximum velocity and time step are inversely related. SPLASH represents the landscape as a grid of square cells and requires spatial inputs. A geographic information system (ArcInfo, ArcView) is used to parameterize maps describing topography, vegetation, and soil.

\section{Example Parameters and Simulations}

For our example set of model simulations, we drew on a combination of site-specific parameters and more generally applicable parameter values. We used data for vegetation cover from the intensively studied Mesita del Buey piñon-juniper woodland at Los Alamos National Laboratory in northern New Mexico (lat $35^{\circ} 50^{\prime} 58^{\prime \prime} \mathrm{N}$, long $106^{\circ} 16^{\prime} 20^{\prime \prime} \mathrm{W}$; Breshears 2008). Vegetation is characterized by a heterogeneous pattern of bare soil and vegetated patches. The woody plant canopy vegetation is composed primarily of Colorado piñon pine (Pinus edulis Engelm.) and one-seed juniper (Juniperus monosperma [Engelm] Sarg.). These two species made up 55\% of the area's tree cover (data were for conditions prior to a recent die-off of piñon pine; Breshears 2008). In the intercanopy spaces, the perennial grass blue grama (Bouteloua gracilis [H.B.K.] Lag.) is the dominant herbaceous species (Wilcox 1994). Within the intercanopy patches, the herbaceous vegetation cover can be either relatively high, $>60 \%$, or low, $<20 \%$ (Reid et al. 1999). A vegetation map was developed from a low-flight aerial photograph (Fig. 1A) by classifying $1 \times 1 \mathrm{~m}$ cells into canopy patches of woody plants, intercanopy patches with relatively high levels of herbaceous vegetation, or intercanopy patches that were mostly bare. We categorized the three patches using on-screen digitation on the basis of pixel color and patch shape, with supplemental field visits used as needed.

We superimposed this vegetation pattern on topography using a 1-m DEM derived from point surveys at the site. The survey included elevations at tree bases and intercanopy low points and hence provides microtopography at the patch scale we were simulating. We generated slope and aspect maps from this DEM using the methods in ArcInfo (Environmental Systems Research Institute, Redlands, CA). The average slope for the area simulated, which was roughly planar, was approximately $6 \%$. We parameterized the soil as homogeneous and corresponding to the dominant soil type, Typic Haplustalfs, with a depth of $78 \mathrm{~cm}$, which was consistent with site conditions. With the exception of the presence of the litter layer in canopy patches, soil properties do not differ significantly between intercanopy and canopy patch types (Davenport et al. 1996). Porosity was calculated from bulk density (Newman 1996) and particle density using the relationship of Brakensiek et al. (1986). Field capacity was calculated from percent sand and percent clay (Reid 1997) using the equation of Saxton et al. (1986). Suction at the wetting front $\left(S_{f}\right)$ was calculated from porosity, percent sand, and percent clay using the equation of Rawls and Brakensiek (1985).

The three vegetation patch types (tree canopy, intercanopy herbaceous, intercanopy bare) were parameterized differently with respect to three surface characteristics: LAI, surface roughness, and saturated hydraulic conductivity. LAI, which affects the interception of precipitation, was assumed to be 0.0 for bare patches, 0.5 for herbaceous intercanopy patches (corresponding to values for shortgrass steppe dominated by the same species as the herbaceous intercanopy patches within the example site; Knight 1973), and 2.5 for tree canopy patches (based on Beeson et al. 2001, and which is within the range for the same species of piñon trees; Classen et al. 2005). A parameter describing surface roughness, Manning's n, was assumed to be 0.05 for bare soil, 0.5 for intercanopy herbaceous patches, and 0.9 for canopy patches (as in Beeson et al. 2001 and modified from Hydrologic Engineering Center 1998). Saturated hydraulic conductivity $\left(K_{s}\right)$, which can vary with vegetation patch type (Roundy et al. 1978; Wood and Blackburn 1981; Wilcox et al. 2003b), was derived from calculations for effective saturated hydraulic conductivity that accounted for vegetation differences (Rawls and Brakensiek 1983; Rawls et al. 1989; Hester et al. 1997), including that canopy patches can exhibit finger flow or bypass infiltration, whereas intercanopies exhibit more uniform piston infiltration (Robinson et al. 2010), and was $4.3 \mathrm{~mm} \cdot \mathrm{h}^{-1}$ for bare soil, $42.6 \mathrm{~mm} \cdot \mathrm{h}^{-1}$ for intercanopy herbaceous patches, and $74.5 \mathrm{~mm} \cdot \mathrm{h}^{-1}$ for canopy patches.

Our example simulations spanned a range of herbaceous covers, beginning with the initially mapped combination of $35 \%$ intercanopy herbaceous cover, $10 \%$ of intercanopy bare cover, and $55 \%$ tree canopy cover (Fig. 1A), and proceeded by reducing herbaceous cover by converting randomly selected remaining herbaceous cover to bare cover (while holding tree canopy cover constant) progressively to levels of $30 \%, 25 \%$, $19 \%, 9 \%, 4 \%$, and $0 \%$ intercanopy herbaceous cover. For each of the seven vegetation combinations, we conducted a simulation that used initial conditions and parameters that were ecologically relevant and likely to generate hillslope runoff. We used a 10-mm design storm, which corresponds to an approximately 1-yr return interval, with storm duration of $6 \mathrm{~h}$ and peak intensity at midevent (Fig. 1C; McLin 1992). Soil water content for each simulation was initialized at field capacity to provide conditions likely to generate runoff and yet still allow infiltration. Each simulation was conducted for $24 \mathrm{~h}$ following the initiation of the precipitation event to ensure that all redistribution of surface flow was complete. We calculated total runoff leaving the bottom of the hillslope over the 24-h simulation period. For each vegetation patch type, we calculated runoff and run-on per cell and total flow into and out of all cells of each patch type.

\section{Example of Patch-Hillslope Runoff Redistribution}

Our example results show that in general-and not surprisingly-runoff at the hillslope scale increased with decreasing intercanopy herbaceous cover and notably exhibited a nonlin- 
Intercanopy herbaceous cover (\%)
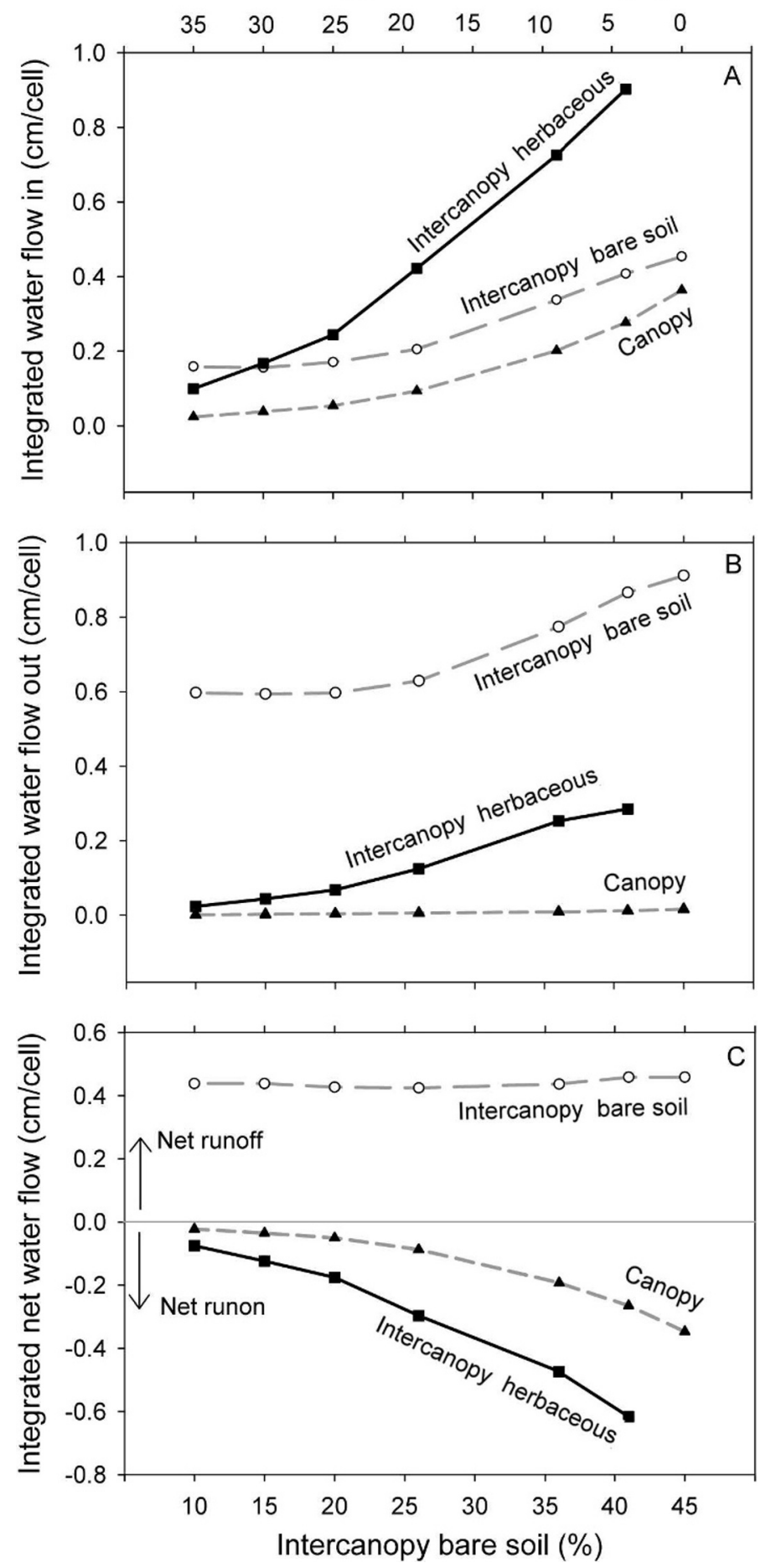

Figure 2. On a per-cell basis: $\mathbf{A}$, flow out, $\mathbf{B}$, flow in, and $\mathbf{C}$, net run-on and runoff for each cell type versus the intercanopy herbaceous cover (top $X$ axis) and the intercanopy bare soil cover (bottom $X$ axis). Values for $0 \%$ herbaceous cover are not included because there is no herbaceous capture of run-on in this case.

ear threshold-like response (Fig. 1D). Runoff increased slightly when herbaceous cover was decreased from the initial value of $35 \%$ down to $19 \%$ but increased substantially when herbaceous cover was further reduced to $9 \%$ and then $4 \%$, culminating in peak runoff at $0 \%$ herbaceous cover. On a
Intercanopy herbaceous cover (\%)
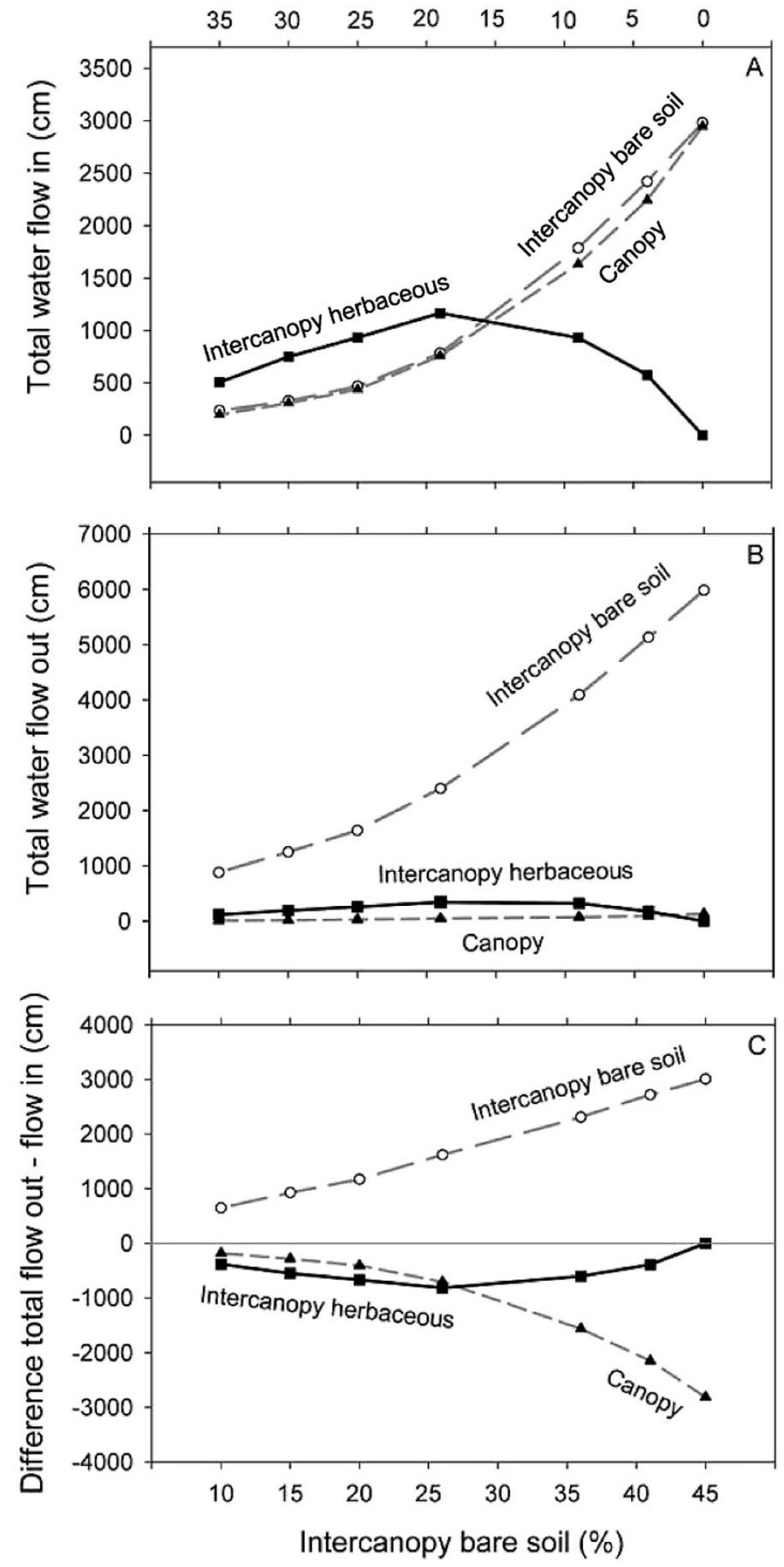

Figure 3. Total flows, as summed for each patch type: A, total flow in, $\mathbf{B}$, total flow out, and $\mathbf{C}$, total run-on into and runoff from the given patch type-intercanopy bare soil, intercanopy herbaceous, and canopy-and for each of the seven simulated scenarios. Values for $0 \%$ herbaceous cover are not included because there is no herbaceous capture of run-on in this case.

per-cell basis (Fig. 2), at the scale of the grid cell $\left(1 \mathrm{~m}^{2}\right)$, bare cells exhibited a relatively constant net runoff flow out of each cell independent of the amount of herbaceous cover (Fig. 2C). Conversely, herbaceous cells exhibited increased net run-on into each cell as the amount of herbaceous cells decreased; tree 


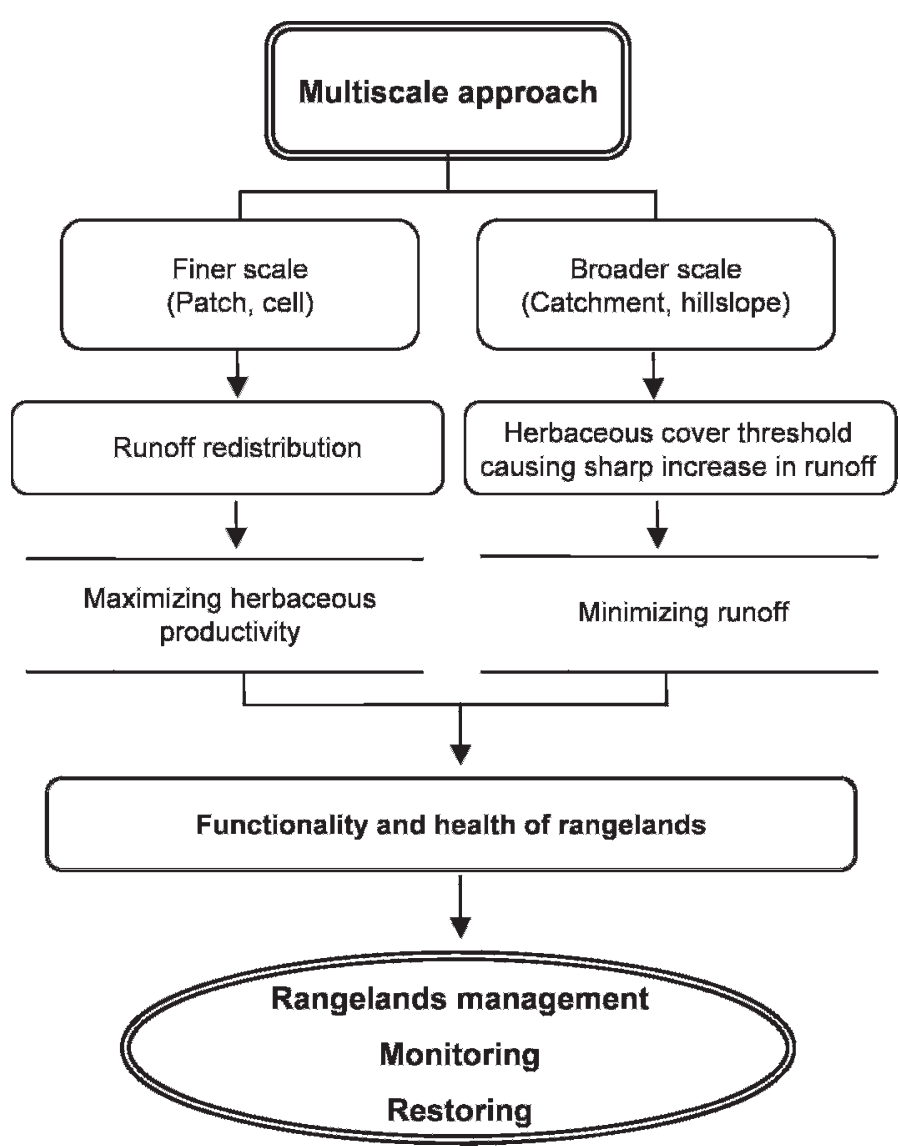

Figure 4. Conceptual linkages between how maximization of run-on to herbaceous patches relates to minimization of hillslope-scale runoff (upper portion) and their relevance to rangeland management, monitoring, and restoration (lower portion).

canopy cells exhibited a similar but more muted response (Fig. 2C).

Notably, for total amount of flow per patch type (Fig. 3), total flow into all herbaceous patches (run-on) was greatest when the amount of bare cover was intermediate $(26 \%$ bare cover and 19\% herbaceous cover), highlighting a trade-off between source area for generating runoff (total flow out; Fig. 3B) and sink area for capturing run-on (Fig. 3A). The difference between total flow into and out of all herbaceous cells was not very sensitive to changes in the amount of herbaceous cover (Fig. 3C), highlighting how total run-on captured by herbaceous patches occurs at an intermediate level of herbaceous cover (Fig. 3A) - a finding with implications for herbaceous vegetation and its management.

\section{ON THE REDISTRIBUTION OF RUNOFF}

Our results build on well-documented differences in infiltration and associated runoff among rangeland vegetation patch types (e.g., Roundy et al. 1978; Wood and Blackburn 1981; Reid et al. 1999; Wilcox et al. 2003b; Lebron et al. 2007; Madsen et al. 2008; Robinson et al. 2010). These spatial differences have important implications for runoff and erosion at the hillslope scale (Bergkamp et al. 1998; Davenport et al. 1998; Wilcox et al. 2003a). The ecohydrological significance of these relation- ships is being increasingly recognized (Ludwig et al. 2005). When a threshold level of bare cover is exceeded at the hillslope scale (Fig. 1D) and the ecosystem loses efficiency at trapping runoff, it becomes "leaky" or "nonconserving" (Ludwig and Tongway 2000; Wilcox et al. 2003a). A positive feedback loop may then reinforce the degradation process by which higher runoff rates can produce higher erosion rates and less of the incoming precipitation is captured by plants (Davenport et al. 1998; Wilcox et al. 2003a).

The results of our example that included explicit spatial redistribution of runoff are consistent with a simpler example based on percolation theory in which a single algorithm links bare patches to determine hillslope-scale runoff and erosion (Davenport et al. 1998). Our example and the percolation theory example both show a threshold-like response in hillslope runoff and erosion, although the threshold was less pronounced in our example here, likely because we accounted for how amount of capture is influenced by both roughness and infiltration. Improving predictions of these threshold-like responses is central to improving our understanding of how such mosaics of vegetation patches in rangelands work.

Our example simulation provides additional insights into these runoff-run-on redistribution processes at the patch as well as hillslope scale (Fig. 4, upper portion). With respect to flow into and out of cells on a per-cell basis, our example results are consistent with general empirical observations in rangelands (Bergkamp et al. 1998; Reid et al. 1999; Willcox et al. 2003a). Bare patches generated the same amount of net runoff independent of changes in herbaceous cover, whereas herbaceous patches captured increasingly more run-on per patch as herbaceous cover was replaced with bare cover. However, the total amount of run-on capture by a vegetation patch type depends on the product of the amount of herbaceous cover and the amount of capture per herbaceous cell, such that both terms need to be considered in determining the optimum amount of total capture by herbaceous patches. This relationship ties directly to a central tenant of ecohydrology that runoff redistribution from bare to vegetated patches concentrates the key limiting resource of water such as to optimize vegetation amount (Rodriguez-Iturbe 2000; Eagelson 2002; Ludwig et al. 2005). The large inputs and outputs on a per-cell basis overall highlight the high degree to which water is redistributed among vegetation patches in these rangeland mosaics. The patch- and hillslope-scale results are also consistent with other recent studies that highlight the importance of spatial patterns of high and low ground cover in determining runoff and erosion (Bartley et al. 2006). Runoff and erosion increase as the spatial pattern of vegetation becomes more coarse and the connectivity of runoff source areas increases (Bautista et al. 2007; Mayor et al. 2008).

\section{MANAGEMENT IMPLICATIONS}

The amount of herbaceous cover capturing the maximum amount of run-on occurred prior to exceeding the threshold at which bare patches become highly interconnected and trigger a threshold-like response in hillslope runoff. Rangeland management often focuses not only on herbaceous cover but more directly on biomass and productivity. Vegetation growth and productivity depend not only on the amount of vertical rainfall 
but also on the amount of water redistributed laterally by surface runoff-run-on (Ludwig et al. 2005; Yu et al. 2008). Our example illustrates an optimal level of herbaceous cover for which runoff is reconcentrated. This redistribution of runoff likely increases plant-available water and should translate into increases in per-plant biomass and productivity (Ludwig et al. 2005). Consequently, rangeland management could potentially be improved by focusing on this optimum value for capture by herbaceous patches (Fig. 4, lower portion).

Rangeland monitoring has progressed to consider herbaceous cover and its spatial pattern (Ludwig et al. 1997). We support this general approach but additionally suggest scientists and managers should consider the potentially enhanced biomass and productivity that are expected from enhanced run-on capture. Because reductions in herbaceous cover below the level of optimal capture of run-on by herbaceous cover are associated with the transition to a large increase in runoff and associated erosion, caution must be applied in managing toward this optimum. Nonetheless, our example illustrates the need to integrate consideration of how source-sink areas depend on relative proportions of bare and herbaceous patches but can also influence those patches by concentrating runoff in a way likely to enhance biomass and productivity.

In summary, we propose that scientists and land managers consider how maximization of run-on to herbaceous patches relates to minimization of hillslope-scale runoff. Doing so relates a key concept in ecohydrology - that runoff redistribution from bare to vegetated patches concentrates water and enhances vegetation growth and biomass-to the general issue that reductions in intercanopy herbaceous cover can lead to a threshold-like response triggering a large increase in hillslope runoff and associated losses of soil sediment and nutrients. In our example simulation, we illustrate that the total amount of runon for all herbaceous patches was greatest when the amount of bare cover was intermediate, highlighting a trade-off between source area for generating runoff and sink area for capturing run-on. Of course, the specific nature of patch-hillslope runoff redistribution responses will depend on several site-specific conditions, but the general nature of the response exhibited in our example simulation may be broadly applicable to other rangelands. We suggest that a more robust suite of such relationships could be valuable for managing rangelands by explicitly accounting for optimality and trade-offs in biomass per herbaceous patch, total herbaceous cover, and prevention of hillslope-scale connectivity of bare patches that triggers a large increase in runoff and associated sediment and nutrients.

\section{ACKNOWLEDGMENTS}

We thank Darin J. Law, John A. Ludwig, Juan C. Villegas, and anonymous reviewers for comments and assistance and Craig D. Allen, Shirley A. Kurc, Kevin D. Reid, and Bradford P. Wilcox for discussion of related concepts.

\section{LITERATURE CITED}

Abrahams, A. D., A. J. Parsons, and J. Wainwright. 1995. Effects of vegetation change on interrill runoff and erosion, Walnut Gulch, southern Arizona. Geomorphology 13:37-48.
Anderson, V. J., And K. C. Hodgkinson. 1997. Grass-mediated capture of resource flows and the maintenance of banded mulga in a semi-arid woodland. Australian Journal of Botany 45:331-342.

Bartley, R., C. H. Roth, J. Ludwig, D. McJannet, A. Liedloff, J. Corfield, A. Hawdon, AND B. АвBотt. 2006. Runoff and erosion from Australia's tropical semi-arid rangelands: influence of ground cover for differing space and time scales. Hydrological Processes 20:3317-3333.

Bautista, S., A. G. Mayor, J. Bourakhouadar, and J. Bellot. 2007. Plant spatial pattern predicts hillslope runoff and erosion in a semiarid Mediterranean landscape. Ecosystems 10:987-998.

Beeson, P. C., S. N. Martens, and D. D. Breshears. 2001. Simulating overland flow following wildfire: mapping vulnerability to landscape disturbance. Hydrological Processes 15:2917-2930.

BergKAMP, G. 1998. A hierarchical view of the interactions of runoff and infiltration with vegetation and microtopography in semiarid shrublands. Catena 33:201-220.

Bhark, E., and E. Small. 2003. The relationship between plant canopies and the spatial variability of infiltration in grasslands and shrublands of the northern Chihuahuan desert, N.M. Ecosystems 6:185-196.

Boer, M., and J. Puigdefábregas. 2005. Effects of spatially structured vegetation patterns on hillslope erosion in a semiarid Mediterranean environment: a simulation study. Earth Surface Processes and Landforms 30:149167.

Brakensiek, D. L., W. J. Rawls, and G. R. Stephenson. 1986. A note on determining soil properties for soils containing rock fragments. Journal of Range Management 39:408-409.

BRESHEARS, D. D. 2008. Structure and function of woodland mosaics: consequences of patch-scale heterogeneity and connectivity along the grasslandforest continuum. In: 0. W. Van Auken [ED.]. Western North American Juniperus communities. New York, NY, USA: Ecological Studies Series, Springer. p. 58-92.

Briske, D. D., S. D. Fuhlendorf, and F. E. Smeins. 2006. A unified framework for assessment and application of ecological thresholds. Rangeland Ecology and Management 59:225-236.

Classen, A. T., J. Demarco, S. C. Hart, T. G. Whitham, N. S. Cobb, and G. W. Koch. 2005. Long-term pinyon litterfall dynamics in response to soil stress and herbivory. Ecosystems 8:62-72.

Cornet, A., C. Montana, J. P. Delhoume, and J. Lopez-Portillo. 1992. Water flows and the dynamics of desert vegetation stripes. In: A. J. Hansen and F. Di Castri [EDS.]. Landscape boundaries: consequences for biotic diversity and ecological flows. New York, NY, USA: Springer-Verlag. p. 327-345.

Courant, R., K. O. Friedrichs, and H. Lewy. 1928. Uber die partiellen differenzengleichngen der mathematishen physik. Mathematische Annalen 100:32-74.

Davenport, D. W., D. D. Breshears, B. P. Wilcox, and C. D. Allen. 1998. Viewpoint: sustainability of piñon-juniper ecosystems-a unifying perspective of soil erosion thresholds. Journal of Range Management 51:231-240.

Davenport, D. W., B. P. Wilcox, and D. D. Breshears. 1996. Soil morphology of canopy and intercanopy sites in a piñon-juniper woodland. Soil Science Society of America Journal 60:1881-1887.

Dingman, S. L. 1993. Physical hydrology. Englewood Cliffs, NJ, USA: Prentice Hall. $575 \mathrm{p}$.

Dregne, H. E. 2002. Land degradation in the drylands. Arid Land Research and Management 16:99-132.

Eagelson, P. S. 2002. Ecohydrology: Darwinian expression of vegetation form and function. Cambridge, United Kingdom: Cambridge University Press. $443 \mathrm{p}$.

Elwell, H. A., and M. A. Stocking. 1976. Vegetal cover to estimate soil erosion hazard in Rhodesia. Geoderma 15:61-70.

Herrick, J. E., B. T. Bestelmeyer, S. R. Archer, A. J. Tugel, and J. R. Brown. 2006. An integrated framework for science-based arid land management. Journal of Arid Environments 65:319-335.

Herrick, J. E., J. W. Van Zee, K. M. Havstad, and W. G. Whitford. 2005. Monitoring manual for grassland, shrubland and savanna ecosystems. Volume 1. Quick start. Tucson, AZ, USA: University of Arizona Press. 36 p. 
Hester, J. W., T. L. Thurow, and C. A. Taylor, JR. 1997. Hydrologic characteristics of vegetation types as affected by prescribed burning. Journal of Range Management 50:199-204.

Hydrologic Engineering Center. 1998. HEC-1 Flood Hydrograph Package users manual, CPD-1A. Davis, CA, USA: US Army Corps of Engineers, Hydrologic Engineering Center. $434 \mathrm{p}$.

Imeson, A. C., AND H. Lavee. 1998. Soil erosion and climate change-the transect approach and the influence of scale. Geomorphology 23:219-227.

KNIGHT, D. H. 1973. Leaf area dynamics of a shortgrass prairie in Colorado. Ecology 4:891-896.

Lebron, I., M. D. Madsen, D. G. Chandler, D. A. Robinson, O. Wendroth, and J. Belnap. 2007. Ecohydrological controls on soil moisture and hydraulic conductivity within a pinyon-juniper woodland. Water Resources Research 43:W08422.

Lesschen, J. P., J. M. Schoorl, and L. H. Cammeraat. 2009. Modelling runoff and erosion for a semi-arid catchment using a multi-scale approach based on hydrological connectivity. Geomorphology 109:174-183.

LudWIG, J. A., AND D. J. Tongway. 1995. Spatial organization of landscapes and its function in semi-arid woodlands, Australia. Landscape Ecology 10:51-63.

LudWIG, J. A., AND D. J. Tongway. 2000. Viewing rangelands as landscape systems. In: 0. Arnalds and S. Archer [EDS.]. Rangeland desertification. Dordrecht, The Netherlands: Kluwer Academic. p. 39-52.

Ludwig, J. A., D. J. Tongway, D. Freudenberger, J. Noble, and K. Hodgkinson. 1997. Landscape ecology function and management: principles from Australia's Rangelands. Collingwood, Australia: CSIR0 Publications. $158 \mathrm{p}$.

Ludwig, J. A., B. Wilcox, D. D. Breshears, D. J. Tongway, and A. C. Imeson. 2005 Vegetation patches and runoff-erosion as interacting ecohydrological processes in semiarid landscapes. Ecology 86:288-297.

Madsen, M. D., D. G. Chandler, and J. Belnap. 2008. Spatial gradients in ecohydrologic properties within a pinyon-juniper ecosystem. Ecohydrology 4:349-360.

Martens, S. N., ANd D. D. Breshears. 2005. Assessing contaminant transport vulnerability in complex topography using a distributed hydrologic model. Vadose Zone Journal 4:811-818.

Mayor, A. G., S. Bautista, E. E. Small, M. Dixon, and J. Bellot. 2008. Measurement of the connectivity of runoff source areas as determined by vegetation pattern and topography: a tool for assessing potential water and soil losses in drylands. Water Resources Research 44:W10423.

McDonald, A. K., R. J. Kinucan, AND L. E. Loomis. 2009. Ecohydrological interactions within banded vegetation in the northern Chihuahuan Desert, USA Ecohydrology 2:66-71.

McLin, S. G. 1992. Determination of 100-year floodplain elevations at Los Alamos National Laboratory. Los Alamos, NM, USA: Los Alamos National Laboratory Report LA-12195. $83 p$.

Middleton, N. J., And D. S. G. Thomas. 1997. World atlas of desertification. London, United Kingdom: Edward Arnold. 182 p.

Newman, B. D. 1996. Geochemical investigations of calcite fracture fills and mesatop water dynamics on the Pajarito Plateau, New Mexico [thesis]. Socorro, NM, USA: New Mexico Institute of Mining and Technology. 235 p.

Newman, B. D., B. P. Wilcox, S. Archer, D. D. Breshears, C. N. Dahm, C. J. Duffy, N. G. McDowell, F. M. Phillips, B. R. Scanlon, and E. R. Vivoni. 2006. The ecohydrology of arid and semiarid environments: a scientific vision. Water Resources Research 42:W06302.

Noy-Meir, I. 1973. Desert ecosystems: environment and producers. Annual Review of Ecology and Systematics 4:25-51.

Pierson, F. B., J. D. Bates, T. J. Svejcar, and S. P. Hardegree. 2009. Runoff and erosion after cutting western juniper. Rangeland Ecology and Management 60:285-292.

Pyke, D. A., J. E. Herrick, P. Shaver, and M. Pellant. 2002. Rangeland health attributes and indicators for qualitative assessment. Journal of Range Management 55:584-597.

Rawls, W. J., and D. L. Brakensiek. 1983. A procedure to predict Green Ampt infiltration parameters. In: Proceedings of the American Society of Agricultural
Engineers Conference on Advances in Infiltration. St. Joseph, MI, USA: ASAE publication. p. 102-112.

Rawls, W. J., AND D. L. BRakensiek. 1985. Prediction of soil water properties for hydrologic modeling. In: E. B. Jones and T. J. Ward [EDS.]. Proceedings of the Symposium: Watershed management in the Eighties; April 30-May 1, 1985; Denver, CO, USA. New York, NY, USA: American Society of Civil Engineers. p. 293-299.

Rawls, W. J., D. L. Brakensiek, and R. Savabi. 1989. Infiltration parameters for rangeland soils. Journal of Range Management 42:139-142.

REID, K. D. 1997. Runoff and sediment yield in a semiarid piñon-juniper woodland, New Mexico [thesis]. Fort Collins, C0, USA: Colorado State University. $114 \mathrm{p}$.

Reid, K. D., B. P. Wilcox, D. D. Breshears, and L. MacDonald. 1999. Runoff and erosion in a piñon-juniper woodland: influence of vegetation patches. Soil Science Society of America Journal 63:1869-1879.

Robinson, D. A., I. Lebron, R. J. Ryel, And S. B. Jones. 2010. Soil water repellency: a method of moisture sequestration in pinyon-juniper woodland. Soil Science Society of America Journal 74:624-634.

Rodríguez-Iturbe, I. 2000. Ecohydrology: a hydrologic perspective of climate-soilvegetation dynamics. Water Resources Research 36:3-9.

Roundy, B. A., W. H. BLACKBURn, And R. E. Eckert, JR. 1978. Influence of prescribed burning on infiltration and sediment production in the pinyon-juniper woodland, Nevada. Journal of Range Management 31:250-253.

Saxton, K. E., W. J. Rawls, J. S. Romberger, and R. I. Papendick. 1986. Estimating generalized soil-water characteristics from texture. Soil Science Society of America Journal 50:1031-1036.

Schlesinger, W. H., A. D. Abrahams, A. J. Parsons, and J. Wainwright. 1999. Nutrient losses in runoff from grassland and shrubland habitats in Southern New Mexico: I. Rainfall simulation experiments. Biogeochemistry 45:21-34.

Schlesinger, W. H., T. J. Ward, and J. Anderson. 2000. Nutrient losses in runoff from grassland and shrubland habitats in southern New Mexico: II. Field plots. Biogeochemistry 49:69-86.

THORNES, J. B. 1990. Vegetation and erosion. Chichester, United Kingdom: Wiley. $518 \mathrm{p}$.

Tongway, D. J., AND J. A. LudWIG. 1997. The conservation of water and nutrients within landscapes. In: J. A. Ludwig, D. Tongway, D. Freudenberger, J. Noble, and K. Hodgkinson [EDS.]. Landscape ecology function and management: principles from Australia's rangelands. Melbourne, Victoria, Australia: CSIRO. p. 13-22.

Wainwright, J., A. J. Parsons, and A. D. Abrahams. 2000. Plot-scale studies of vegetation, overland flow and erosion interactions: case studies from Arizona and New Mexico. Hydrological Processes 14:2921-2943.

Weltz, M. A., M. R. Kidwell, And H. D. Fox. 1998. Influence of abiotic and biotic factors in measuring and modeling soil erosion on rangelands: state of knowledge. Journal of Range Management 51:482-495.

WILCOX, B. P. 1994. Runoff and erosion in intercanopy zones of pinyon-juniper woodlands. Journal of Range Management 47:285-295.

Wilcox, B. P., D. D. Breshears, and C. D. Allen. 2003a. Ecohydrology of a resource conserving semiarid woodland: effects of scale and disturbance. Ecological Monographs 73:223-239.

Wilcox, B. P., D. D. Breshears, and H. J. TuRin. 2003b. Hydraulic conductivity in a piñon-juniper woodland: influence of vegetation. Soil Science Society of America Journal 67:1243-1249.

WILCOX, B. P., AND T. L. ThuRow. 2006. Emerging issues in rangeland ecohydrology: vegetation change and the water cycle. Rangeland Ecology \& Management 59:220-224.

Wood, M. K., and W. H. BLackBuRn. 1981. Grazing systems: their influence on infiltration rates in the Rolling Plains of Texas. Journal of Range Management 34:331-335.

Yu, M., Q. Gao, H. E. Epstein, and X. Zhang. 2008. An ecohydrological analysis for optimal use of redistributed water among vegetation patches. Ecological Applications 18:1679-1688. 